\title{
Geologic grazing refuges and grassland diversity: A shortgrass steppe study
}

\author{
DANIEL G. MILCHUNAS, AND IMANUEL NOY-MEIR
}

Authors are Research Scientist, Forest, Range, and Watershed Stewardship Department and Natural Resource Ecology Laboratory, Colorado State University, Fort Collins, Colo. 80523, USA; and Professor, Department of Agricultural Botany, Institute of Plant Sciences, Faculty of Agricultural, Food and Environmental Quality Sciences, Hebrew University of Jerusalem, P.O.B. 12, Rehovot 76100, Israel.

\section{Abstract}

Geologically isolated, natural grazing refuges that have never been grazed by domestic livestock can be foci of diversity for rare species. This study compared refuges protected from grazing by ravines to adjacent grazed sites in an uncommon grassland type in eastern Colorado. We also tested whether differences between refuge and grazed sites were due to protection from grazing versus abiotic conditions, based on temporary caging of little bluestem plants (Schizachyrium scoparium [Michaux] Nash). Regionally rare species were not exclusive to refuges, but occurred also on adjacent grazed sites. However, refuges showed greater species richness, as well as greater abundance of several tall stature species that are uncommon in the surrounding shortgrass steppe. Temporary protection of little bluestem plants in grazed sites resulted in significant changes in growth and reproductive output, in the direction of refuge plants. Though this geological refuge did not manifest an exclusive set of rare species as reported from other systems, it does preserve strong source populations of uncommon species that are sensitive to grazing and thereby contributes to regional grassland diversity.

Key Words: refugia, relict, diversity, herbivory, rare species, livestock grazing, rock bluffs and outcrops, drought

Natural refuges from grazing herbivores occur throughout the world in both geologic and biotic forms (buttes, rock outcrops, spiny plants, etc.). Both forms of physical protection can be important in structuring landscape diversity or in maintaining undisturbed relict communities amidst a surrounding disturbed landscape (Clements 1934, Fenner et al. 1993, Callaway et al. 2000, Milchunas and Noy-Meir 2002). Natural grazing refuges may be different from experimental grazing exclosures because they often existed before the introduction of domesticated animals, thereby potentially better representing 'pristine' conditions and more likely to harbor remnant plant populations. A review of studies of refuges (Milchunas and Noy-Meir 2002) compared to

This work was funded through the US-Israel Bi-national Science Foundation (BSF 96-00112), NSF (DEB 00-87255), and the Shortgrass Steppe LTER (NSF DEB 9632852. DEB 021653). We thank Don Hazlett for taxonomic consultation and accomplishing the floristic survey, Cheryl Danz for additional help in data collection, and Mark Ball of the USDA-Forest Service, Pawnee National Grassland, for logistical support.

Correspondence: Daniel G Milchunas, Daniel.Milchunas@colostate.edu phone: (970) 491-6691, FAX (970) 491-2156

Manuscript accepted 27-May 03.

\section{Resumen}

Geológicamente aislados, los refugios naturales frente al pastoreo que no han sido nunca pastados por el ganado domÈstico pueden ser focos de diversidad de especies raras. Este estudio comparó refugios protegidos frente al pastoreo debido a barrancos con lugares adyacentes pastados en un pastizal poco com n en el Este de Colorado.

También comprobamos si las diferencias entre los refugios y los lugares pastados fueron debidas a la protección del pastoreo o a las condiciones abióticas, utilizando para ello la protección temporal de plantas de "little bluestem" Schizachyrium scoparium [Michaux] Nash). Las plantas raras a una escala regional no fueron exclusivas de los refugios, sino que aparecieron también en los lugares adyacentes pastados. Sin embargo, los refugios mostraron una mayor riqueza de especies, así como una mayor abundancia de varias especies de porte alto que son poco comunes en la pradera de gramIneas cortas circundante. La protección temporal de las plantas de "little bluestem" en los lugares pastados produjo cambios significativos en el crecimiento y rendimiento reproductivo, en la dirección de las plantas de los refugios. Estos refugios de origen geológico no presentaron un grupo exclusivo de plantas raras como ha sido documentado en otros sistemas; no obstante, preservan importantes poblaciones fuente de especies poco comunes que son sensibles al pastoreo y de este modo contribuyen a la diversidad regional de los pastizales.

reviews of experimental exclosures (Milchunas and Lauenroth 1993 ) indicates relatively few studies of geologic refuges.

Communities with a short evolutionary history of grazing are generally more sensitive to grazing (Milchunas et al. 1988, Milchunas and Lauenroth 1993) and refuges may more likely be unique (Milchunas and Noy-Meir 2002). Rare plant species have been found mainly confined to cliffs of grazed islands off the California coast (Moran 1967), cliff ledges in alpine communities (Lee and Lavers 1990), rocky bluffs in grasslands (Fenner et al. 1993) and forest cliffs (Sykes 1969) in New Zealand. However, refuges can also be important in systems with a long evolutionary history of grazing. The numerous rock outcrops of northern Israel harbor genetically important wild ancestors to our current-day wheats and barleys, as well as a variety of other tall, grazing sensitive species (Zohary and Brick 1961, Noy-Meir 1990, NoyMeir et al. 1991a, 1991b). This suggests that refuges can play an important role in conserving plant diversity even in systems with a long evolutionary history of grazing. 
Our objectives were to characterize geologic refuges in the shortgrass steppe, with a long history of grazing by native bison, and to assess if refuge effects were due to the lack of grazing, or to other environmental differences in the refuge. The physical structure of buttes, mesas, and outcrops may have an effect on environmental conditions, and a review of studies showed that none attempted to control for this additional factor that may also influence plant growth and the presence of particular plant species (Milchunas and NoyMeir 2002).

We studied productive, unique tallgrass communities disjunct and isolated by the surrounding shortgrass steppe region. Because of the isolated nature of the refuges in this area with a long history of grazing, we did not expect to find rare or unusual plant species more abundant in the refuges compared to the grazed sites, as often observed in other situations (Milchunas and Noy-Meir 2002). Because tall species are generally less grazing tolerant than short species, we expected that grazing would result in homogeneity of landscape diversity (beta diversity) by producing communities more similar to the shortgrass steppe community, both compositionally and structurally. Growth measurements were made of a target species in grazed sites compared to temporarily caged plants to assess whether response was in a direction towards condition of plants in the refuge, which would suggest a grazing refuge effect rather than environmental effects of the geologic structure.

\section{Methods}

The study was conducted in the Pawnee National Grasslands of the USDA Forest Service, and the study area located near north-facing bluffs near the Pawnee Buttes, about $16 \mathrm{~km}$ northeast of Keota, Colorado (lat. $40^{\circ} 49^{\prime} \mathrm{N}$, long. $103^{\circ}$ $\left.58^{\prime} \mathrm{W}\right)$. We surveyed a number of types of potential refuge study areas in eastern Colorado, including buttes, mesas, and ravine-isolates. The few buttes and mesas posed problems because of logistics, lack of sufficient replicates, and land ownership, but the ravine-isolated area did not present these problems and provided ungrazed-grazed replicate sites in an unusual plant community. The community dominant was a species that is common in the tallgrass prairie of North America (little bluestem Schizachyrium scoparium [Michaux] Nash) but is confined to small local habitats in the shortgrass steppe region. This community-type is not recognized by the Natural Heritage Program; an organization that maps and classifies plant communities throughout the U.S. Three other communities recognized in Colorado that have little bluestem as a co-dominant are considered imperiled and rare globally and in Colorado (Colorado Natural Heritage Program 1997). Therefore, it can be assumed that the community that our study sites were in is rare. Visually, the community is strikingly much more productive aboveground and comprised of a greater proportion of tall species than the surrounding shortgrass steppe, possibly due to soils and/or winter snow accumulation along the steep-sided bluffs that border the north side.

Grazing in this area was relatively light compared to much of the shortgrass steppe of the National Grassland; removal of standing biomass at the end of the grazing season in mid-October was visually estimated at about $30-35 \%$. This compares to about $50-60 \%$ average removal in most neighboring shortgrass steppe areas (Milchunas et al. 1989, M. Marston USFS personal commun.). The light grazing intensities in the study area reflect management considerations for the recreational use of the bluff and butte area. Annual precipitation at the nearby Central Plains Experimental Range averages $321 \mathrm{~mm}, 71$ $\%$ of which falls during the May through September growing season. The years 1998 and 1999 were above average precipitation, followed by a severe drought in 2000 until late in the growing season.

Five sites of ravine-isolated refuges were located that had steep enough walls to prevent access by livestock, but not to deer or small mammals, and that had adjacent grazed sites. We found one very old, cow fecal pat on one of the refuge sites we eventually used for study. Fecal pats in this semiarid system are identifiable for more than 6 years after being deposited (Lussenhop et al. 1982). The paired grazed-ungrazed sites spanned a linear distance of approximately $2.5 \mathrm{~km}$ along the base of the bluffs. All sites slope downward from a high, very steep bluff ridge. The refuge sites are triangular in shape, with the bluff on the upslope side and deeply eroded ravine walls on the other 2 sides. Refuge sites ranged in size from approximately 0.1 ha to 0.5 ha. Grazed sites had similar lengths at the bluff-wall side, had ravines on the other 2 sides, but did not form the isolated triangular shape of refuge sites because the ravines were positioned perpendicular to the bluffs. The grazed sites were of indefinite area because they graded smoothly out into the usual shortgrass steppe community with no border opposite the bluff border. Soils from the base of the bluff wall are chalky white siltstone (Keota series), a weakly developed Ustic Torriorthent. This unusual soil supports a plant community unlike that of the surrounding open plains; sometimes referred to as siltstone barrens (Hazlett 1998). This study was not conducted in the barrens plant community that is located very close to the bluffs, but in a community intermediate between the siltstone barrens and shortgrass steppe. This community is dominated by little bluestem, while the 3 recognized communities in Colorado with little bluestem have it as a co-dominant and associated with species not common in this community. Analyses of 1937 compared to 1995 aerial photos indicated no detectable erosional changes over that period, suggesting a very long period of isolation from herbivores.

We first conducted a floristic survey to determine richness and the occurrence of any rare species. Rare species were classified and identified by a taxonomist that has done extensive collecting in the Pawnee National Grasslands and surrounding areas (Hazlett 1998). A triangular plot of 0.1 ha was delineated on all 10 sites to survey species richness on an equal area basis (area based on smallest refuge site). All species found in each treatment (refuge or grazed) site were recorded, and the number of individuals of any rare species counted (number of stems emerging from the ground). Frequencies of occurrence coefficients were calculated for various lifeforms and groups of species, based on presence or absence in the 5 sites of each treatment. For a 2 species group example, if species A was present on only 1 of the 5 sites of a particular treatment and species B was absent on all sites of that treatment, then the frequency of occurrence would be calculated as $1 / 10=0.1$ (or 1 occurrence out of the possible 10) for that particular treatment. A value of 0 indicates none of the species in the group were present in any of the 5 sites of that treatment, and a value of 1 indicates that all species in the group were present in all 5 sites of that treatment.

Classification into life-forms/functional groups was based on Hazlett (1998). "Weeds" were species occurring along roadsides and/or disturbed soil, and included the following species: goat's beard (Tragopogon dubius Scopuli ssp. major (Jacquin) Vollmann), Platte thistle (Cirsium canescens Nuttall), stickseed (Lappula occidentalis (S. Watson) 
Greene), peppergrass (Lepidium densiflorum Schrader), yellow sweet clover (Melilotus officinalis (L.) Lam.), combleaf evening primrose (Oenothera coronopifolia Torrey \& Gray), wire lettuce (Stephanomeria pauciflora (Torrey) A. Nelson), and Fendler's threeawn (Aristida purpurea Nuttall var. fendleriana (Steudel) Vasey). An index of relative distribution was based on the number of states the species has been identified in (Hazlett 1998), with "restricted distribution" representing species identified in from 3 to 9 states, and "widespread distribution" representing species identified in from 28 to 48 states. Nomenclature follows Great Plains Flora Association (1986).

Quantitative estimates of community composition were obtained on each of the 5 grazed and each of the 5 refuge sites along five, $50 \mathrm{~m}$ long transects with five, $0.25-\mathrm{m}^{2}$ quadrats spaced evenly along each transect (125 quadrats/treatment). The start of transects were randomly located parallel to the bluff, and then run perpendicular down the slope. Transects were not placed closer than $10 \mathrm{~m}$ to the base of the bluff or $5 \mathrm{~m}$ to the edge of the ravine. The entire area of each site was sampled, rather than just the 0.1 ha plots used in the floristic survey, and some transects had to be shorter at 2 smaller sites. Cover of species, bare ground, and litter were estimated to the nearest $1 \%$ when cover was less than $10 \%$, and to the nearest $5 \%$ when cover was over $10 \%$.

An experiment was conducted to determine whether differences between the refuge and grazed treatments were due to physical factors associated with the refuge or to the lack of grazing. No unusually rare or threatened plants were found in sufficient abundance across the 10 plots to use as a target species for the experimental work. Little bluestem was chosen as a target species for temporary exclosure to grazing livestock by cages and comparison of individual plant performance in refuge populations, grazed non-refuge populations, and caged temporarily ungrazed non-refuge populations. We refer to these treatments as refuge, grazed, and caged, respectively. Little bluestem was selected because of its general absence from the common shortgrass steppe community, its dominance in the bluff community, the disjunct nature of the species in this region, the unusual tall stature of the species relative to most shortgrass communities, and visual estimates that suggested cover was greater in refuge than grazed sites (44 vs $33 \%$ ).

In October 1997, sturdy concrete reinforcement wire-mesh $(10 \mathrm{~cm} \times 10 \mathrm{~cm}$ mesh) cages were constructed for use as temporary exclosure cages in grazed sites. These rectangular cages were about $1 \mathrm{~m} \mathrm{x}$ $1.5 \mathrm{~m} \mathrm{x} 0.5 \mathrm{~m}$ high, and open at the bottom. Side corners were fastened together with metal hog-rings. Five cages at each of the 5 grazed sites were placed over target plants, and secured to the ground with metal tent stakes on each side. Locations for the cages were chosen based on the presence of 2 individual target plants that were greater than $3 \mathrm{~m}$ apart but less than $10 \mathrm{~m}$ apart. Cages were distributed evenly down the slope, and then placed randomly parallel to the slope. This assured paired caged and grazed plants along the slightly sloping gradient down from the base of the bluff. Caged versus grazed plants in the pair were chosen by flip of coin. Refuge plants were similarly chosen and randomized over the gradient (non-caged only).

Plant measurements were made in late July of 1998, 1999, and 2000. For each of the 75 target individuals, plant height and basal circumference were measured, and the number of flowering and non-flowering tillers counted. Height was to the top of the basal leaves, not of seed stalk tillers. Basal circumference was measured by wrapping a cloth measuring tape snugly around the plant just above crown level. This measure is a function of plant "leafyness" as well as being influenced by tiller number.

For individual species, differences in frequency of occurrence (presence) in quadrats between refuge and grazed sites were tested by the Chi-square test or by Fisher's exact test where applicable. Differences in mean cover between treatments were tested by the Kruskal-Wallis test (the non-parametric test was preferred because distribution of species cover was not normal in most cases). Species that occurred in only a few quadrats were not analyzed or not presented.

Association coefficients (A) of plant species in refuge $(R)$ relative to grazed $(G)$ treatments were calculated based on a coefficient similar to that used to express diet selectivity or preference of foraging animals:

$$
A(R / G)=(f r-f g) /(f r+f g)
$$

where $\mathrm{fr}$ and $\mathrm{fg}$ are the proportion of quadrats where the species occurred in refuge and grazed quadrats respectively. The coefficient ranges from a minimum of -1 to a maximum of +1 and represent a gradient of greater presence in grazed to greater presence in refuge treatment. A similar community association coefficient was also calculated from the mean cover data.

Differences in growth of the target species in grazed, caged, and refuge treat- ments were tested by analysis of variance for each year, with Tukey's honestly significant difference used to separate means at $P<0.05$. Logarithmic (for size measurements) and square root (for number of tillers) transformations were applied to data to satisfy normality assumptions. A non-parametric test (Kruskal-Wallis) was also used to test for differences between plots independent of variable distribution. For categorical response variables, contingency tables and the Chi-square test were used. In some cases, initial plant size at the beginning of the experiment (as In circumference) was added as a covariate in the analysis of variance. The difference between the first and last measurement of a response variable (In transformed) was in some cases used as a new response variable to assess temporal trend. $\mathrm{R}^{2}$ indicates the proportion of variance accounted for by ANOVA.

\section{Results}

Floristic survey and quantitative estimates of grazed and refuge plant community structure

Never-grazed refuge sites contained a similar number of plant species (species richness) as grazed sites. Of the 94 identified in all 10, 0.1 ha plots, 10 species were exclusive to grazed and 14 to refuge sites. Counts of individuals of 7 rare species indicated a patchy distribution among sites, and no indication that any were more abundant in the refuge (Table 1). The total numbers of individuals for all 7 species were slightly greater in grazed (96) than refuge (75) sites.

Frequencies of occurrence were calculated based on presence or absence of individual species for particular groups of species across the $5,0.1$ ha treatment plots. The frequency of occurrence of species with restricted and widespread distributions was similar between grazed and refuge sites (Table 2). The frequency of occurrence of "weed" annual, perennial, forb, cacti, and tree species were similar in the 5 grazed sites and 5 refuge sites. Only species of grasses and shrubs had differences in frequencies between treatments. Species of shrubs were more frequent on refuge sites and species of grasses more frequent on grazed sites.

Quantitative abundance measurements based on species cover indicate that grazed and refuge sites differ in species composition and in life-form and functional group composition (Table 3). All species that were highly associated with refuge sites are uncommon components of 
Table 1. Density of rare species (see Methods) in refuge and grazed sites in a Colorado little bluestem community, based on searching entire 0.1 ha areas in each of $\mathbf{1 0}$ treatment-replicates.

\begin{tabular}{|c|c|c|c|c|c|c|c|c|c|c|c|c|}
\hline \multirow[b]{2}{*}{ Species } & \multicolumn{5}{|c|}{ Refuge Replicate } & \multicolumn{7}{|c|}{ Non-Refuge Replicate } \\
\hline & 1 & 2 & 3 & 4 & 5 & Total & 1 & 2 & 3 & 4 & 5 & Total \\
\hline & \multicolumn{12}{|c|}{. n n n } \\
\hline Astragalus kentrophyta A. Gray var. kentrophyta & 2 & 0 & 2 & 0 & 2 & 6 & 0 & 3 & 1 & 0 & 1 & 5 \\
\hline Cryptantha cana (A. Nelson) Payson [Oreocarya] & 2 & 0 & $\mathbf{0}$ & 0 & $\mathbf{0}$ & 2 & 0 & 5 & 0 & 0 & 1 & 6 \\
\hline Dalea candida Willdenow var. oligophylla (Torrey) Shinners & 0 & 5 & 4 & 1 & 1 & 11 & 2 & 5 & 0 & 7 & 8 & 22 \\
\hline Dalea purpurea Ventenat var. purpurea & $\mathbf{0}$ & $\mathbf{0}$ & $\mathbf{0}$ & $\mathbf{0}$ & 0 & 0 & 0 & 2 & 0 & 0 & 3 & 5 \\
\hline Eriogonum alatum Torrey var. alatum [Pterogonum] & 1 & 8 & 21 & 2 & 21 & 53 & 3 & 17 & 1 & 6 & 31 & 58 \\
\hline Leptodactylon caespitosum Nuttall & 1 & 0 & 0 & $\mathbf{0}$ & 0 & 1 & 0 & 0 & 0 & 0 & $\mathbf{0}$ & 0 \\
\hline Stenotus armerioides Nuttall var. armerioides [Haplopappus] & 2 & 0 & $\mathbf{0}$ & 0 & 0 & 2 & 0 & 0 & 0 & 0 & 0 & 0 \\
\hline
\end{tabular}

the vast surrounding shortgrass steppe community. Note that "uncommon" in this context is in reference to the relative abundance in the shortgrass steppe, and does not imply that the species is regionally or globally rare or uncommon. In contrast, some species that are dominant or common components of the shortgrass steppe community were more abundant in grazed than refuge sites. The species associated with the shortgrass steppe included the dominant grass (blue grama [Bouteloua gracilis (H.B.K.) Lag.]), dominant forb (scarlet globemallow [Sphaeralcea coccinea (Pursh) Rydb.]), and dominant grass-like (threadleaf sedge [Carex filifolia Nutt.]), as well as other common species such as needle-and-thread grass (Stipa comata Trin. and Rupr.) All these species were found in significantly greater abundance in grazed sites. Four of the 6 species uncommon in the shortgrass steppe with high associations with refuge sites displayed a statistically significant association, while only one uncommon shortgrass steppe species was significantly associated more with grazed sites.

Diversity of the treatments differed in species sampled uniquely and in number per unit area. Thirteen species were sampled only in refuge sites compared to only 5 in grazed sites. The number of species per quadrat averaged 3.86 in refuge and 3.56 in grazed sites, and this difference was significant.

Physiognomy of refuge sites also differed from adjacent grazed sites. Tall grasses and forbs and woody species predominated in refuge sites compared to short species in grazed sites (Table 3 ). The response of species to grazing was not consistently related to palatability.

\section{Experimental evaluation of the} response of little bluestem, a refugepreferring species, to short-term protection from grazing

Plant height in all 3 years was lower in open, grazed sites compared to caged plants in the grazed sites, reflecting the direct removal by the grazers (Table 4a). Caged plants were of intermediate height compared to grazed and refuge plants, and this was significant in 2 of the 3 years. Changes in plant height (and all response variables) from 1998 to 2000 were negative, reflecting the drought conditions during the last year. Refuge plants displayed a greater decline from 1998 to 2000 than did non-refuge plants (whether caged or grazed). Grazed plants retained a similar height through time, but this could just reflect constant management rather than any response to environmental conditions.

No significant effect of grazing treatment was observed for basal circumference in 1998 and 1999 (Tables 4b, 5). However, under the drought conditions of 2000 the greater circumference of refuge compared to grazed plants was significant, and the response to caging on the grazed sites was significant only at $\mathrm{P}=0.10$. There was a highly significant positive cage effect when considering the change in basal circumference from 1998 to 2000 or when removing initial variation between individuals by taking 1998 circumference as covariate (Table $4 b, 5,6$ ). The decrease in basal circumference from 1998 to 2000 was significantly less in caged plants than in either grazed or refuge plants.

Table 2. Frequency of occurrence coefficients for various plant categories and life-forms in five, 0.1 ha sites for each refuge and grazed sites in a Colorado little bluestem community. A value of 0 indicates none of the species in the group were present in any of the 5 sites of that treatment, and a value of 1 indicates that all species in the group were present in all 5 sites of that treatment. $A$ total of 94 species were identified in the 10 sites. See Methods for definitions.

\begin{tabular}{lccc}
\hline \hline Plant Group & \multicolumn{2}{c}{ Frequency of Occurrence } & Number of \\
& Refuge & 0.43 & $\begin{array}{c}\text { Nume } \\
\text { Species }\end{array}$ \\
\hline Restricted Distribution & 0.43 & 0.42 & 14 \\
Widespread Distribution & 0.34 & 0.38 & 13 \\
Weeds & 0.35 & 0.30 & 8 \\
Annuals & 0.28 & 0.51 & 8 \\
Perennials & 0.47 & 0.73 & 86 \\
Grasses & 0.63 & 0.44 & 12 \\
Forbs & 0.42 & 0.76 & 74 \\
Shrubs & 0.92 & 0.20 & 1 \\
Trees & 0.20 & 0.50 & 2 \\
Cacti & 0.50 & &
\end{tabular}


Table 3. Percent cover of $\mathbf{2 2}$ most common species in refuge and grazed sites, association coefficients of species for the refuge sites, abundance of the species in typical shortgrass steppe communities, and height and palatability characteristics. Species are ordered from high association with the refuge sites to high association with the grazed sites.

\begin{tabular}{|c|c|c|c|c|c|c|c|}
\hline Species & Refuge & & Grazed & $\begin{array}{l}\text { Association } \\
\text { Coefficient }\end{array}$ & Abundance $^{1}$ & Height & Palatability \\
\hline & \multicolumn{3}{|c|}{-... (\% cover $) \ldots . .}$. & & & & \\
\hline Solidago canadensis L. var. gilvocanescens Rydberg & 0.06 & * & 0.00 & 1.000 & Uncommon & Tall & Low \\
\hline Comandra umbellate (L.) Nuttall var. pallida (A. DC.) Jones & 0.37 & ** & 0.07 & 0.673 & Uncommon & Mid & Low \\
\hline Calamovilfa longifolia (Hooker) Scribner var. longifolia & 2.19 & ** & 0.46 & 0.671 & Uncommon & Tall & High \\
\hline Schizachyrium scoparium (Michaux) Nash var. Scoparium [Andropogon] & 19.26 & ** & 5.34 & 0.566 & Uncommon & Tall & Med \\
\hline Rhus aromatica Aiton var. trilobata (Nuttall ex Torrey \& Gray) & 0.84 & & 0.39 & 0.364 & Uncommon & Woody & Low \\
\hline Calylophus lavandulifolius (Torrey \& Gray) Raven & 0.14 & & 0.05 & 0.360 & Uncommon & Mid & Med \\
\hline Artemisia frigida Willdenow & 0.32 & & 0.17 & 0.311 & V.common & Woody & Low \\
\hline Gaura coccinea Nuttall ex Pursh & 0.11 & & 0.06 & 0.273 & V.common & Tall & High \\
\hline Astragalus tenellus Pursh & 0.21 & & 0.12 & 0.268 & Common & Tall & Low, \\
\hline Yucca glauca Nuttall var. glauca & 1.96 & * & 1.45 & 0.150 & Common & Tall & Low $^{2}$ \\
\hline Gutierrezia sarothrae (Pursh) Britton \& Rusby & 0.52 & & 0.42 & 0.111 & Dominant & Woody & Low \\
\hline Krascheninnikovia lanata (Pursh) Meeuse \& smit [Ceratoides \& Eurotia] & 0.53 & & 0.56 & -0.029 & Uncommon & Woody & High \\
\hline Arenaria hookeri Nuttall spp. hookeri [Alsinaceae: Eremogone] & 0.10 & & 0.11 & -0.037 & Uncommon & Short & Low \\
\hline Carex filifolia Nuttall & 3.36 & * & 4.51 & -0.146 & Dominant & Short & Med \\
\hline Stipa comata Trinius \& Ruprecht [Hesperostipa] & 6.93 & $* *$ & 12.03 & -0.269 & V.common & Tall & Low $^{2}$ \\
\hline Aristida purpurea Nuttall var. longiseta (Steud.) Vasey [A. longiseta Steud.] & 0.26 & & 0.46 & -0.281 & Common & Short & Low \\
\hline Bouteloua gracilis (Humboldy, Bonpland \& Kunth) Lagasca [Chrondosum] & 5.82 & ** & 10.98 & -0.307 & Dominant & Short & Med \\
\hline Lesquerella ludoviciana (Nuttall) S. Watson & 0.03 & & 0.06 & -0.333 & Common & Short & Low \\
\hline Eriogonum alatum Torrey var. alatum [Pterogonum] & 0.04 & & 0.10 & -0.412 & Uncommon & Mid & High \\
\hline Psoralidium lanceolatum (Pursh) Rydberg [Psoralea $]$ & 0.01 & & 0.14 & -0.700 & Uncommon & Mid & High \\
\hline Sphaeralcea coccinea (Pursh) Rydberg var. coccinea & 0.05 & $*$ & 0.27 & -0.700 & Dominant & Short & High \\
\hline Astragalus adsurgens Pallas var. robustior Hooker & 0.04 & ** & 0.28 & -0.750 & Uncommon & Short & Low \\
\hline
\end{tabular}

** $\mathrm{P}<0.01, * \mathrm{P}<0.05$, between refuge vs grazed sites.

${ }^{1}$ Abundance based on sampling in Milchunas et al. (1989), Milchunas and Lauenroth (1995), and Rebollo et al. (2002) and palatability based on sampling in Rebollo et al. (2002).

${ }^{2}$ Can be opposite at particular times of the year.

Responses in number of flowering tillers for the 3 treatments were very similar to those for total tiller number. However, the positive refuge effect was in this case significant in all 3 years (Tables $4 d, 5$ ). The response of caged plants in flowering tillers was more rapid than the response in total tiller numbers or for basal circumference.

\section{Discussion}

Within the rare community found near bluffs, natural refuges provide additional protection to a set of species that are absent or rare in the shortgrass steppe communities that dominate the landscape across vast areas. This may be considered an increase in landscape diversity, even though the distinct, unusual community is not greatly altered or converted to shortgrass steppe when grazed at the present low intensity. All species found in the refuges were also found in adjacent grazed sites when an intensive floristic survey was done. However, the dominant species of the rare community (little bluestem) increased in the refuges and the heavily dominant species of the shortgrass steppe plant community (blue grama) increased in the grazed sites relative to the refuges in the little bluestem community. This was true for several other species that are asso-
Table 4. Plant height, basal circumference, number of tillers, and number of flowering tillers of little bluestem grazed (non-refuge), caged (non-refuge temporarily ungrazed), and refuge (never grazed) sites, measured in July over 3 years, and mean changes $(\Delta)$ in those variables from 1998 to 2000. Ln and Sqrt are analyses on natural log and square root transformed data, and $R^{2}$ is the proportion of variance accounted for by ANOVA.

a. Plant Height $(\mathrm{cm})$

\begin{tabular}{lllll}
\hline \multicolumn{1}{c}{ Treatment } & 1998 & 1999 & 2000 & $\Delta 2000-1998$ \\
\hline Grazed & $11.7^{1} \mathrm{a}$ & $12.9 \mathrm{a}$ & $11.6 \mathrm{a}$ & $-0.1 \mathrm{~b}$ \\
Caged & $17.9 \mathrm{~b}$ & $19.3 \mathrm{~b}$ & $16.7 \mathrm{~b}$ & $-1.2 \mathrm{~b}$ \\
Refuge & $23.1 \mathrm{c}$ & $21.3 \mathrm{~b}$ & $19.5 \mathrm{c}$ & $-3.6 \mathrm{a}$ \\
\hdashline $\mathrm{R}^{2}$ (adjusted $^{2}$ ) & 0.52 & 0.39 & 0.33 & 0.04
\end{tabular}

b. Basal Circumference (cm)

\begin{tabular}{|c|c|c|c|c|c|}
\hline Treatment & 1998 & 1999 & 2000 & $\Delta 2000-1998$ & $\Delta \operatorname{Ln} 2000-1998$ \\
\hline Grazed & 63 & 65 & $56 a$ & $-7.6 \mathrm{a}$ & $-0.14 a$ \\
\hline Caged & 65 & 67 & $62 a b$ & $-2.7 b$ & $-0.03 b$ \\
\hline Refuge & 74 & 75 & $67 \mathrm{~b}$ & $-7.2 \mathrm{a}$ & $-0.10 \mathrm{a}$ \\
\hline $\mathrm{R}^{2}$ (adjusted) & 0.01 & 0.01 & 0.03 & 0.10 & 0.14 \\
\hline
\end{tabular}

\begin{tabular}{llllll}
\hline c. Total Number of Tillers & & & & & \\
\hline Treatment & 1998 & 1999 & 2000 & $\Delta 2000-1998$ & $\Delta$ Sqrt 2000-1998
\end{tabular}

\begin{tabular}{|c|c|c|c|c|c|}
\hline Treatment & 1998 & 1999 & 2000 & $\begin{array}{l}\Delta 2000-1998 \\
\end{array}$ & $\Delta$ Sqrt 2000-1998 \\
\hline Grazed & 107 & 107 & $65^{\mathrm{a}}$ & $-42 a$ & $-2.36 \mathrm{a}$ \\
\hline Caged & 106 & 116 & $76 a b$ & $-30 b$ & $-1.63 b$ \\
\hline Refuge & 141 & 142 & $111 \mathrm{~b}$ & $-30 b$ & $-1.47 b$ \\
\hline $\mathrm{R}^{2}$ (adjusted) & 0.02 & 0.02 & 0.06 & 0.14 & 0.45 \\
\hline
\end{tabular}

\begin{tabular}{llllll}
\hline d. Number of Flowering Tillers & & & & & \\
\hline Treatment & 1998 & 1999 & 2000 & $\Delta 2000-1998$ & $\Delta$ Sqrt 2000-1998
\end{tabular}

\begin{tabular}{|c|c|c|c|c|c|}
\hline Treatment & 1998 & 1999 & 2000 & $\Delta 2000-1998$ & $\Delta$ Sqrt $2000-1998$ \\
\hline Grazed & $61 \mathrm{a}$ & $63 a$ & $33 a$ & $-28 a$ & $-2.29 a$ \\
\hline Caged & $70 \mathrm{ab}$ & $77 a b$ & $50 a$ & $-21 b$ & $-1.47 b$ \\
\hline Refuge & $103 b$ & $101 \mathrm{~b}$ & $81 b$ & $-22 b$ & $-1.29 b$ \\
\hline $\mathrm{R}^{2}$ (adjusted) & 0.07 & 0.06 & 0.13 & 0.07 & 0.51 \\
\hline
\end{tabular}

${ }^{1}$ Values within columns not sharing a common letter are significantly different.

${ }^{2}$ Adjusted $R^{2}$ s are more conservative than raw $R^{2}$ s. 
Table 5. Significance and variance explained $\left(\mathbf{R}^{2}\right)$ by models for plant circumference (natural logarithm transformation), total number of tillers and number of flowering tillers (both square root transformation) of little bluestem plants in relation to the 5 paired sites, location (non-refuge and refuge), and caging (caged and grazed).

\begin{tabular}{|c|c|c|c|c|}
\hline Variable & $\mathrm{R}^{2}$ (adjusted) & Paired Site & Location & Caging \\
\hline Ln circumference 1998 & 0.05 & $(*)$ & $(*)$ & NS \\
\hline Ln circumference 1999 & 0.05 & $(*)$ & $(*)$ & NS \\
\hline Ln circumference 2000 & 0.06 & NS & * & $(*)$ \\
\hline$\Delta \operatorname{Ln}$ circumference $1998-2000$ & 0.12 & NS & NS & $* * *$ \\
\hline VNumber of tillers 1998 & 0.12 & ** & $(*)$ & NS \\
\hline$\sqrt{ }$ Number of tillers 1999 & 0.14 & $* * *$ & * & NS \\
\hline$\sqrt{ }$ Number of tillers 2000 & 0.17 & ** & ** & NS \\
\hline$\Delta \sqrt{ }$ Number of tillers $1998-2000$ & 0.44 & NS & $* * *$ & $* * *$ \\
\hline$\sqrt{ } \mathrm{N}$ inflorescences 1998 & 0.15 & $* *$ & ** & NS \\
\hline$\sqrt{ } \mathrm{N}$ inflorescences 1999 & 0.16 & $* *$ & $* *$ & NS \\
\hline$\sqrt{ } \mathrm{N}$ inflorescences 2000 & 0.21 & $* *$ & $* * *$ & $*$ \\
\hline$\Delta \sqrt{ } \mathrm{N}$ inflorescences $1998-2000$ & 0.51 & NS & $* * *$ & $* * *$ \\
\hline
\end{tabular}

***P $<0.0001,{ }^{* *} \mathrm{P}<0.01,{ }^{*} \mathrm{P}<0.05,\left({ }^{*}\right) \mathrm{P}<0.10$, NS $\mathrm{P}>0.10$

ciated with the shortgrass steppe plant community. For example, the dominant forb species of the shortgrass steppe (scarlet globemallow) and the dominant carex species (threadleaf sedge) were also more abundant in the grazed than the refuge little bluestem community. Further, species such as pale comandra (Comandra umbellata [L.] Nutt.), wire lettuce (Stephanomeria pauciflora [Torr.] A. Mels), and lavenderleaf primrose (Calylophus lavandulifolius [T. and G.] Raven) are rarely found in open shortgrass steppe plant communities but are a significant component of the little bluestem community near the bluffs. These species are much more abundant inside the refuges than in grazed sites outside.

The refuges also augment structural diversity of the landscape, since short species associated more strongly with grazed little bluestem communities are primary components of the shortgrass steppe and tall species are more strongly associated with little bluestem communities of the refuge sites. The affinity of uncommon shortgrass steppe species to the refuge and of dominant shortgrass steppe species to the grazed bluff communities indicates that the refuges have the effect of creating a more distinct separation between community types. Based on Whittaker's (1952) index of community association, dissimilarity between lightly grazed and ungrazed refuge sites averaged $43 \%$, compared to an average of only $15 \%$ dissimilarity between heavily grazed and ungrazed shortgrass steppe (Milchunas et al. 1989). Light grazing in the tall, productive buttes community has a greater effect than heavy grazing of shortgrass steppe communities.

Although plant species and landscape diversity were greater, no particularly rare species were found in refuge sites that were not present in grazed sites. This is in contrast to that found in many communities with a short evolutionary history of grazing (Milchunas and Noy-Meir 2002). Plant species diversity of refuge compared to grazed sites did not differ in terms of rare species located through intensive floristic survey of presence or absence. However, diversity at the small scale (quadrat) and the site scale (uniquely sampled species) was greater in refuge sites

Table 6. Significance and variance explained $\left(\mathbf{R}^{2}\right)$ by models for plant circumference (natural logarithm transformation), total number of tillers, and number of flowering tillers (both square root transformation) of little bluestem plants in relation to the 5 paired sites, location (non-refuge and refuge), and caging (caged and grazed), with initial (1998) values of plant size (In circumference, square root of number of tillers and of flowering tillers) as a covariate.

\begin{tabular}{lccccc}
\hline \hline Variable & $\mathrm{R}^{2}$ (adjusted) & Paired Site & Location & Caging & Initial Value \\
\hline Ln circumference 1999 & 0.93 & NS & NS & NS & $* * *$ \\
Ln circumference 2000 & 0.91 & NS & $*$ & $* * *$ & $* * *$ \\
$\Delta$ Ln circumference 1998-2000 & 0.18 & NS & $*$ & $* * *$ & $* *$ \\
V Number of tillers 1999 & 0.94 & NS & NS & $* *$ & $* * *$ \\
V Number of tillers 2000 & 0.98 & NS & $* * *$ & $* * *$ & $* * *$ \\
$\Delta \sqrt{ }$ Number of tillers 1998-2000 & 0.45 & NS & $* * *$ & $* * *$ & $(*)$ \\
$\sqrt{ }$ inflorescences 1999 & 0.94 & NS & NS & $*$ & $* * *$ \\
$\sqrt{N}$ inflorescences 2000 & 0.98 & NS & $* * *$ & $* * *$ & $* * *$ \\
$\Delta \sqrt{ }$ inflorescences 1998-2000 & 0.52 & NS & $* * *$ & $* * *$ & $(*)$ \\
\hline
\end{tabular}

***P $<0.0001,{ }^{* * P}<0.01,{ }^{*} \mathrm{P}<0.05,\left(^{*}\right) \mathrm{P}<0.10, \mathrm{NS} \mathrm{P}>0.10$. compared to grazed sites. Similar results have been observed in the common shortgrass steppe communities surrounding the bluff communities sampled here (Milchunas et al. 1989).

Experimental results from short-term exclosures indicated that grazed little bluestem plants responded to protection in a directional trajectory towards a status more similar to refuge plants. This would suggest the differences between refuge and non-refuge communities are due directly to grazing by livestock rather than abiotic conditions particular to the geologic refuge. Butler and Briske (1988) also observed reductions in basal areas of little bluestem in response to 2 years of defoliation in more productive post oak savannah communities in Texas. This study also demonstrates that refuge plants can potentially better serve as seed sources to grazed areas than plants existing in grazed areas. These effects may be more pronounced under conditions of heavy grazing. However, while greater seed production is more generally reported in undefoliated compared to defoliated plants (Obeso 1993, Noy-Meir and Briske 1996), this is not always the response in shortgrass steppe. Rebollo et al. (2002) found greater seedhead production in grazed compared to ungrazed shortgrass steppe, except for the dominant blue grama. Also, the geologic features that protect plants from grazers in refuges may also constitute barriers to seed dispersal, depending on the dispersal vector of particular species.

Caged plants tended to increase in tiller numbers during good years while grazed and refuge plants remained stable. During drought, however, refuge plants tended to decline less than either caged or grazed plants. This may suggest that caged plants were able to respond positively during good years of production, but were not yet capable of withstanding drought as well as long-term ungrazed refuge plants. Drought is a common occurrence throughout semiarid and arid western rangelands. Light grazing in some community types may lessen the impacts of drought on particular species (Nelson 1934, Johnson 1956). Increased tillering from a greater number of, but smaller more evenly distributed, tufts in conservatively grazed compared to ungrazed areas was thought to better utilize spatial distribution of soil water in black grama grassland (Nelson 1934). In this study, grazing plus drought stress were additive in reducing tillering of little bluestem in the bluff community. 


\section{Literature Cited}

Butler, J.L. and D.D. Briske. 1988. Population structure and tiller demography of the bunchgrass Schizzchyrium scoparium in response to herbivory. Oikos 51:306-312.

Callaway, R.M., Z. Kikvidze, and D. Kikodze. 2000. Facilitation by unpalatable weeds may conserve plant diversity in overgrazed meadows in the Caucasus Mountains. Oikos 89:275-282.

Clements, F.E. 1934. The relict method in dynamic ecology. J. Ecol. 22:39-68.

Colorado Natural Heritage Program. 1997. Colorado's natural heritage: rare and imperiled animals, plants and plant communities. Natural Heritage Program, Colorado State University, Ft. Collins, Colo., Vol. 3 (1).

Fenner, M., W.G. Lee, and S.J. Duncan. 1993. Chemical features of Chionochloa species in relation to grazing by ruminants in south island, New Zealand. N.Z. J. Ecol.17:35-40.

Great Plains Flora Association. 1986. Flora of the Great Plains. University of Kansas Press, Lawrence, Kan.

Hazlett, D.L. 1998. Vascular plant species of the Pawnee National Grassland. USDAForest Service, Rocky Mountain Research Station, Fort Collins, Colorado, Gen. Tech. Rep. RMRS-GTR-17. 26pp.

Johnson, W.M. 1956. The effect of grazing intensity on plant composition, vigor, and growth of pine-bunchgrass ranges in central Colorado. Ecol. 37:790-798.
Lee, B. and R. Lavers. 1990. Chionochloa Spiralis: Fiordland's forgotten tussock. Forest and Bird, February: 34-35.

Lussenhop, J. D.T. Wicklow, R. Kumar, and J.E. Lloyd. 1982. Increasing the rate of cattle dung decomposition by nitrogen fertilization. J. Range Manage. 35:249-250.

Milchunas, D. G. and W. K. Lauenroth. 1995. Inertia in plant community structure: state changes after cessation of nutrient enrichment stress. Ecol. Applic. 5:452-458.

Milchunas D.G., and W.K. Lauenroth. 1993. A quantitative assessment of the effects of grazing on vegetation and soils over a global range of environments. Ecol. Monogr. 63:327-366.

Milchunas, D.G. and I. Noy-Meir. 2002. Grazing refuges, external avoidance of herbivory and plant diversity. Oikos 99:113-130.

Milchunas, D.G., W.K. Lauenroth, and O.E. Sala. 1988. A generalized model of the effects of grazing by large herbivores on grassland community structure. Amer. Nat. 132:87-106.

Milchunas, D.G., W.K. Lauenroth, P.L. Chapman, and M.K. Kazempour. 1989. Effects of grazing, topography, and precipitation on the structure of a semiarid grassland. Vegetatio 80:11-23.

Moran, R. 1967. Discussion of the flora of Guadalupe Island. Proceedings Biology California Islands, Santa Barbara, Botanical Gardens 69-71.

Nelson, E.W. 1934. The influence of precipitation and grazing upon black grama grass range. Tech. Bull. No. 409. United States Dept. of Agr., Washington, D.C. 32 pp.
Noy-Meir, I., M. Agami, and Y. Anikster. 1991a. Changes in the population density of wild emmer wheat (Triticum turgidum var. dicoccoides) in a mediterranean grassland. Israel J. Bot. 40:385-395.

Noy-Meir, I., M. Agami, E. Cohen, and Y. Anikster. 1991b. Floristic and ecological differentiation of habitats within a wild wheat population at Ammiad. Israel J. Bot. 40:363-384.

Noy-Meir, I., and D.D. Briske. 1996. Fitness components of grazing-induced population reduction in a dominate annual, Triticum dicoccoides (wild wheat). J. Ecol. 84:439-448.

Noy-Meir, I. 1990. The effects of grazing on the abundance of wild wheat, barley and oat. Biol. Conserv. 51:299-310.

Obeso, J.R. 1993. Does defoliation affect reproductive output in herbaceous perennials and woody plant in different ways? Funct Ecol. 7:150-155.

Rebollo, S., D.G. Milchunas, I. Noy-Meir, and P.L. Chapman. 2002. The role of a spiny plant refuge in structuring grazed shortgrass steppe plant communities. Oikos 98:53-64.

Sykes, W.R. 1969. The effect of goats on vegetation of the Kermadec Islands. Proc. N.Z. Ecol. Soc. 16:13-16.

Whittaker, R.H. 1952. A study of summer foliage insect communities in the Great Smoky Mountains. Ecol. Monogr. 22: 1-44.

Zohary, D. and Z. Brick. 1961. Triticum dicoccoides in Israel: notes on its distribution, ecology and natural hybridization. Wheat Information Service 13:6-8. 